\title{
ASUPAN ZAT GIZI MAKRO, STATUS GIZI, DAN STATUS IMUN PADA VEGETARIAN DAN
} NON-VEGETARIAN

\author{
Wanty, Nurmasari Widyastuti, Enny Probosari* ${ }^{*}$ \\ ${ }^{*}$ Departemen Ilmu Gizi Fakultas Kedokteran Universitas Diponegoro \\ Jln. Prof. H. Soedarto, SH., Semarang, Telp (024) 8453708, Email : gizifk@ undip.ac.id
}

\begin{abstract}
Background : Immune status was one of the biomarkers of immune system condition in the body. Vegetarians generally had a lower body mass index (BMI) than non-vegetarians. It had a positive impact on the immune status of vegetarians. Vegetarians were also deficient in some nutrients that can cause adverse effects on vegetarian's immune status. Immune status can be determined by leukocyte count. Leukocyte was the the first immunology which appeared to resist the pathogen.

Objective : To determine the comparison macronutrient intake, nutritional status, and immune status between vegetarians and non-vegetarians.

Methods : Research sample of 64 women were selected through consecutive sampling consisting of 32 vegetarian subjects and 32 non-vegetarian subjects. The weight and height of the subject are measured to determine nutritional status. The macronutrient intakes was measured by Semi Quantitative-Food Frequency Questionnaire (SQ-FFQ) and analyzed using a nutritional software program. Immune status is obtained from the calculation of white blood cells (leukocytes) count. Independent-sample tor Mann-Whitney tests were conducted to evaluate the difference.

Result : There were significant differences in nutritional status $(p=0.019)$, carbohydrate intake $(p=0.002)$, fiber intake $(p=0.001)$, saturated fatty acid $(p=0.001)$, and poly-unsaturated fatty acid $(p=0.001)$ between vegetarians and nonvegetarians.

Conclusion : Carbohydrate intake, fiber intake, and poly-unsaturated fatty acid were higher in vegetarians. Nutritional status and saturated fatty acid intake was higher in non-vegetarians.

Keywords : macronutrient intake, nutritional status, immune status, white blood cell count, leukocyte, vegetarian
\end{abstract}

\begin{abstract}
ABSTRAK
Latar Belakang : Status imun dapat menjadi salah satu penanda kondisi sistem imun di dalam tubuh. Vegetarian umumnya memiliki indeks massa tubuh (IMT) yang lebih rendah dibandingkan dengan non-vegetarian. Hal tersebut memberikan dampak positif terhadap status imun vegetarian. Di samping itu, vegetarian juga mengalami defisiensi beberapa zat gizi yang dapat menyebabkan dampak buruk pada status imun vegetarian. Salah satu penanda status imun tubuh yaitu jumlah leukosit, dimana leukosit merupakan imunologi pertama yang muncul untuk melawan patogen.

Tujuan : Membandingkan asupan zat gizi makro, status gizi, dan status imun antara vegetarian dan non-vegetarian.

Metode : Sampel penelitian sebanyak 64 wanita dipilih melalui consecutive sampling yang terdiri dari 32 subjek vegetarian dan 32 subjek non-vegetarian. Berat badan dan tinggi badan dari subjek diukur untuk menentukan status gizi. Asupan zat gizi makro diukur melalui Semi Quantitative-Food Frequency Questionnaire (SQ-FFQ) dan dianalisis menggunakan program software gizi. Status imun diperoleh dari perhitungan jumlah sel darah putih (leukosit). Analisis statistik yang digunakan yaitu uji T Independen atau Mann-Whitney.

Hasil : Terdapat perbedaan yang signifikan pada status gizi $(p=0.019)$, asupan karbohidrat $(p=0.002)$, asupan serat $(p=0.001)$, asupan lemak jenuh $(p=0.001)$, dan asupan lemak tidak jenuh $(p=0.001)$ antara vegetarian dan nonvegetarian.
\end{abstract}

Simpulan : Asupan karbohidrat, serat, dan lemak tidak jenuh lebih tinggi pada vegetarian sementara status gizi dan asupan lemak jenuh lebih tinggi pada non-vegetarian.

Kata kunci : asupan zat gizi makro, status gizi, status imun, sel darah putih, vegetarian

\section{PENDAHULUAN}

Perkembangan vegetarian di Indonesia dapat dikatakan cukup pesat jika dilihat dari peningkatan jumlah vegetarian yang terdaftar pada Indonesian Vegetarian Society (IVS) dan jumlah rumah makan vegetarian yang sudah ada hingga saat ini. Banyak manfaat yang dapat diperoleh dari seorang vegetarian, salah satunya adalah penurunan berat badan yang dapat mencapai kategori normal. Oleh karena itu, para vegetarian umumnya memiliki Indeks
Massa Tubuh (IMT) yang lebih rendah dibandingkan non-vegetarian. ${ }^{1}$ Beberapa penelitian telah menyebutkan bahwa penurunan berat badan guna mencapai IMT atau status gizi yang normal berhubungan secara positif dengan status imun tubuh. ${ }^{2,3}$

Selain banyak manfaat yang dapat diperoleh, para vegetarian juga memiliki risiko untuk mengalami peningkatan penyakit-penyakit tertentu, salah satunya penyakit infeksi. Salah satu penelitian 
yang dilakukan di London pada populasi Hindu Asian yang merupakan para vegetarian, menyebutkan bahwa terdapat tren peningkatan risiko tuberculosis seiring penurunan frekuensi pengonsumsian daging merah atau ikan dan didukung dengan sebuah penelitian yang dilakukan di India bahwa terdapat hubungan yang signifikan antara vegetarian dengan peningkatan risiko tuberculosis. ${ }^{4}{ }^{5}$ Selain itu, defisiensi beberapa zat gizi yang dialami oleh vegetarian juga memiliki risiko dapat menurunkan status imun yang dimiliki.

Status imun tubuh menjadi salah satu penanda dari kondisi sistem imun di dalam tubuh. Apabila terjadi penurunan status imun maka terjadi penurunan ketahanan (resistensi) tubuh terhadap penyakit terutama infeksi. Status imun sendiri dapat dipengaruhi oleh beragam faktor, antara lain keturunan, usia, hormon, infeksi, alkohol, merokok, asupan zat gizi makro dan mikro. ${ }^{6}$ Berdasarkan kondisi yang sudah dijelaskan, maka peneliti ingin meneliti lebih lanjut mengenai perbandingan asupan zat gizi makro, status gizi, dan status imun pada vegetarian (khususnya pada lacto-ovo vegetarian dan vegan) dan non-vegetarian.

\section{METODE}

Penelitian ini merupakan penelitian observasional dengan desain cross-sectional dan menggunakan metode deskriptif analitik. Penelitian ini termasuk dalam disiplin ilmu gizi masyarakat, bertempat di kota Yogyakarta dan dilakukan pada bulan Desember 2016. Sampel penelitian ini adalah 32 subjek vegetarian yang tergabung dalam Indonesian Vegetarian Society (IVS) cabang Yogyakarta dan 32 subjek non-vegetarian yang merupakan masyarakat umum di Yogyakarta, dimana kedua kelompok dipilih dengan metode consecutive sampling. Kriteria inklusi sampel penelitian ini antara lain berjenis kelamin perempuan, berusia 19-29 tahun, tidak sedang mengalami menstruasi, tidak memiliki aktivitas fisik yang tergolong berat, tidak mengonsumsi obat-obatan atau suplemen apapun, tidak menderita penyakit infeksi atau inflamasi, bersedia menjadi sampel penelitian, dan untuk kelompok vegetarian termasuk dalam golongan lacto-ovo vegetarian dan vegan.

Variabel dalam penelitian ini terdiri dari variabel bebas yaitu vegetarian dan non-vegetarian; serta variabel terikat yaitu status gizi, status imun, dan asupan zat gizi makro berupa asupan energi, karbohidrat, protein, lemak, dan serat. Data yang dikumpulkan antara lain berupa data identitas sampel, riwayat penyakit, dan konsumsi obat-obatan yang diperoleh melalui wawancara kuesioner; data asupan zat gizi makro yang diperoleh melalui wawancara formulir Semi Quantitative-Food Frequency Questionnaire (SQ-FFQ) kemudian dianalisis menggunakan nutrisurvey dan dibandingkan dengan AKG 2013, lalu dikategorikan menjadi tiga yaitu asupan kurang ( $<70 \%)$, cukup (70-120\%), dan lebih $(>120 \%)^{7}$; data antropometri berupa berat badan yang diukur melalui timbangan digital dengan ketelitian $0,1 \mathrm{~kg}$ dan tinggi badan yang diukur menggunakan microtoise dengan ketelitian $0,1 \mathrm{~cm}$; data jumlah leukosit melalui pengambilan darah vena oleh petugas laboratorium; serta data aktivitas fisik melalui wawancara kuesioner aktivitas fisik kemudian dilakukan skoring dan dikategorikan menjadi tiga yaitu aktivitas ringan $(<7,5)$, sedang $(7,5-10)$, dan berat $(>10){ }^{8}$

Analisis statistik yang dilakukan ada dua. Analisis univariat untuk mengetahui karakteristik subjek penelitian dan mendeskripsikan setiap variabel yang diteliti, dimana data kategorik disajikan dalam bentuk distribusi frekuensi sedangkan data numerik disajikan dalam bentuk rata-rata. Analisis bivariat untuk melihat perbedaan antara variabel bebas dengan variabel terikat. Data akan diuji kenormalannya dengan menggunakan uji Kolmogorov-Smirnov. Apabila data berdistribusi normal, uji untuk melihat perbandingan variabel penelitian antara vegetarian dan non-vegetarian menggunakan uji T Independen atau Mann-Whitney apabila data tidak berdistribusi normal.

\section{HASIL PENELITIAN \\ Karakteristik Subjek}

Penelitian ini telah dilakukan pada 64 subjek yaitu 32 subjek vegetarian yang terdiri dari 16 orang vegan dan 16 orang lacto ovo vegetarian dan 32 subjek non-vegetarian.

Berdasarkan tabel 1, rerata IMT dan jumlah leukosit yang dimiliki ketiga kelompok subjek tergolong normal, dan rerata asupan energi, karbohidrat, serat, serta lemak tergolong kurang. Rerata asupan protein pada kelompok non-vegetarian tergolong cukup, namun pada kelompok vegan dan lacto-ovo vegetarian tergolong kurang.

\section{Status Gizi (Indeks Massa Tubuh)}

Berdasarkan tabel 2, jumlah status gizi kurang antara vegan dan non-vegetarian sama, jumlah status gizi normal dan lebih terbanyak pada non-vegetarian.

\section{Asupan Zat Gizi Makro}

Berdasarkan tabel 3, rerata asupan energi, karbohidrat, dan serat antara ketiga kelompok subjek sebagian besar tergolong kurang, sementara rerata asupan protein dan lemak sebagian besar tergolong cukup. 
Tabel 1. Nilai Minimum, Maksimum, Rerata dan Standar Deviasi Karakteristik Subjek Vegetarian dan Non-Vegetarian

\begin{tabular}{|c|c|c|c|c|c|c|c|c|c|}
\hline \multirow[t]{2}{*}{ Karakteristik Subjek } & \multicolumn{3}{|c|}{$\begin{array}{l}\text { Vegan } \\
\mathrm{n}=16\end{array}$} & \multicolumn{3}{|c|}{$\begin{array}{c}\text { Lacto-Ovo Vegetarian } \\
n=16\end{array}$} & \multicolumn{3}{|c|}{$\begin{array}{c}\text { Non-Vegetarian } \\
\mathbf{n}=\mathbf{3 2}\end{array}$} \\
\hline & Min & Maks & Rerata \pm SD & Min & Maks & Rerata \pm SD & Min & Min & Rerata \pm SD \\
\hline Usia responden (tahun) & 20 & 25 & $22 \pm 1.82$ & 20 & 23 & $20.81 \pm 1.11$ & 19 & 19 & $20.75 \pm 1.67$ \\
\hline Lama vegetarian (tahun) & 1 & 25 & $16.88 \pm 9.11$ & 1 & 6 & $3.38 \pm 1.82$ & - & - & - \\
\hline Indeks Massa Tubuh $\left(\mathrm{kg} / \mathrm{m}^{2}\right)$ & 17.2 & 26.6 & $20.41 \pm 3.14$ & 18.5 & 25.5 & $20.47 \pm 2.25$ & 17.8 & 17.8 & $23.57 \pm 5.44$ \\
\hline \multicolumn{10}{|l|}{ Asupan Zat Gizi Makro } \\
\hline Asupan energi (kkal) & 1055 & 1742 & $1446.71 \pm 2.09$ & 733.2 & 2217 & $1524.81 \pm 5.11$ & 1003.1 & 1003.1 & $1473.4 \pm 2.87$ \\
\hline Asupan karbohidrat $(\mathrm{g})$ & 108.5 & 367.4 & $230.77 \pm 78.08$ & 147.8 & 291 & $208.72 \pm 42.1$ & 113.8 & 113.8 & $174.24 \pm 45.71$ \\
\hline$\%$ karbohidrat terhadap energi & 45 & 70 & $58.38 \pm 6.94$ & 43 & 63 & $54.31 \pm 5.7$ & 32 & 32 & $47.41 \pm 8.65$ \\
\hline Asupan protein $(\mathrm{g})$ & 19.5 & 84.9 & $51.14 \pm 19.6$ & 35.4 & 69.7 & $51.89 \pm 10.83$ & 25.3 & 25.3 & $56.83 \pm 18.08$ \\
\hline$\%$ protein terhadap energi & 10 & 19 & $14.19 \pm 3.16$ & 10 & 24 & $16.19 \pm 3.48$ & 9 & 9 & $15.47 \pm 3.68$ \\
\hline Asupan lemak total (g) & 15.8 & 114.2 & $50.9 \pm 25.78$ & 27 & 79.4 & $56.38 \pm 16.03$ & 37.1 & 37.1 & $62.42 \pm 16.37$ \\
\hline$\%$ lemak terhadap energi & 16 & 38 & $27.5 \pm 6.75$ & 22 & 37 & $29.88 \pm 4.77$ & 25 & 25 & $37.06 \pm 6.05$ \\
\hline Lemak Jenuh & 3.2 & 35.8 & $22.4 \pm 12.01$ & 4.2 & 31.6 & $25 \pm 8.4$ & 18.8 & 18.8 & $35.91 \pm 9.80$ \\
\hline Lemak Tidak Jenuh & 7.5 & 22.1 & $12.82 \pm 3.77$ & 5.4 & 19.4 & $9.78 \pm 4.34$ & 2.7 & 2.7 & $6.98 \pm 2.61$ \\
\hline Asupan serat $(\mathrm{g})$ & 8.6 & 35.8 & $19.62 \pm 7.68$ & 3.7 & 41 & $17.38 \pm 9.78$ & 3 & 3 & $6.01 \pm 2.08$ \\
\hline Leukosit $(\mathrm{sel} / \mu \mathrm{L})$ & 5840 & 12550 & $8620 \pm 1.95$ & 4120 & 13550 & $6975.62 \pm 2.75$ & 5680 & 14550 & $8689.69 \pm 2.35$ \\
\hline
\end{tabular}

Tabel 2. Distribusi Frekuensi Status Gizi Subjek Vegetarian dan Non-Vegetarian

\begin{tabular}{|c|c|c|c|c|c|c|}
\hline \multirow{3}{*}{ Kategori } & \multicolumn{6}{|c|}{ Frekuensi } \\
\hline & \multicolumn{2}{|c|}{ Vegan } & \multicolumn{2}{|c|}{ Lacto-Ovo Vegetarian } & \multicolumn{2}{|c|}{ Non-Vegetarian } \\
\hline & (n) & $(\%)$ & (n) & $(\%)$ & (n) & $(\%)$ \\
\hline Kurang & 6 & 37.5 & 0 & 0 & 6 & 18.75 \\
\hline Normal & 8 & 50 & 14 & 87.5 & 16 & 50 \\
\hline Lebih & 2 & 12.5 & 2 & 12.5 & 10 & 31.25 \\
\hline
\end{tabular}

Tabel 3. Distribusi Frekuensi Asupan Zat Gizi Makro Subjek Vegetarian dan Non-Vegetarian

\begin{tabular}{|c|c|c|c|c|c|c|}
\hline \multirow{3}{*}{ Kategori } & \multicolumn{6}{|c|}{ Frekuensi } \\
\hline & \multicolumn{2}{|c|}{ Vegan } & \multicolumn{2}{|c|}{ Lacto-Ovo Vegetarian } & \multicolumn{2}{|c|}{ Non-Vegetarian } \\
\hline & (n) & $(\%)$ & (n) & $(\%)$ & (n) & $(\%)$ \\
\hline \multicolumn{7}{|l|}{ Asupan Energi } \\
\hline Kurang & 11 & 68.75 & 7 & 43.75 & 22 & 68.75 \\
\hline Cukup & 5 & 31.25 & 9 & 56.25 & 10 & 31.25 \\
\hline Lebih & 0 & 0 & 0 & 0 & 0 & 0 \\
\hline \multicolumn{7}{|c|}{ Asupan Karbohidrat } \\
\hline Kurang & 6 & 37.5 & 10 & 62.5 & 27 & 84.38 \\
\hline Cukup & 10 & 62.5 & 6 & 37.5 & 5 & 15.62 \\
\hline Lebih & 0 & 0 & 0 & 0 & 0 & 0 \\
\hline \multicolumn{7}{|l|}{ Asupan Protein } \\
\hline Kurang & 8 & 50 & 1 & 6.25 & 7 & 21.88 \\
\hline Cukup & 7 & 43.75 & 12 & 75 & 17 & 53.12 \\
\hline Lebih & 1 & 6.25 & 3 & 18.75 & 8 & 25 \\
\hline \multicolumn{7}{|l|}{ Asupan Lemak } \\
\hline Kurang & 8 & 50 & 7 & 43.75 & 12 & 37.5 \\
\hline Cukup & 8 & 50 & 8 & 50 & 15 & 46.88 \\
\hline Lebih & 0 & 0 & 1 & 6.25 & 5 & 15.62 \\
\hline \multicolumn{7}{|l|}{ Asupan Serat } \\
\hline Kurang & 9 & 56.25 & 11 & 68.75 & 32 & 100 \\
\hline Cukup & 7 & 43.75 & 4 & 25 & 0 & 0 \\
\hline Lebih & 1 & 6.25 & 0 & 0 & 0 & 0 \\
\hline
\end{tabular}

Tabel 4. Distribusi Frekuensi Status Imun Subjek Vegetarian dan Non-Vegetarian

\begin{tabular}{lcccccc}
\hline & \multicolumn{6}{c}{ Frekuensi } \\
\cline { 2 - 7 } Kategori & \multicolumn{3}{c}{ Vegan } & \multicolumn{2}{c}{ Lacto-Ovo Vegetarian } & \multicolumn{2}{c}{ Non-Vegetarian } \\
\cline { 2 - 7 } & $(\mathbf{n})$ & $(\boldsymbol{\%})$ & $(\mathbf{n})$ & $(\mathbf{\%})$ & $(\boldsymbol{\%})$ \\
\hline Rendah & 0 & 0 & 3 & 18.75 & 0 & 0 \\
Normal & 14 & 87.5 & 11 & 68.75 & 27 & 84.38 \\
Tinggi & 2 & 12.5 & 2 & 12.5 & 5 & 15.62 \\
\hline
\end{tabular}




\section{Status Imun (Jumlah Leukosit)}

Berdasarkan tabel 4, jumlah leukosit yang tergolong rendah terbanyak di kelompok lacto-ovo vegetarian, sementara yang tergolong normal dan lebih terbanyak pada kelompok non-vegetarian.
Perbandingan Status Gizi, Asupan Energi, Karbohidrat, Protein, Lemak, Serat dan Status Imun antara Vegetarian dan Non-Vegetarian

Hasil analisis uji statistik yang dicantumkan pada tabel 5 menunjukkan bahwa terdapat perbedaan yang signifikan pada indeks massa tubuh $(\mathrm{p}=0.019)$, asupan karbohidrat $(\mathrm{p}=0.002)$, serat $(\mathrm{p}=0.001)$, lemak jenuh $(\mathrm{p}=0.001)$, dan lemak tidak jenuh $(\mathrm{p}=0.001)$ antara vegetarian dan non-vegetarian.

Tabel 5. Analisis Perbandingan Status Gizi, Asupan Zat Gizi Makro, dan Status Imun pada Subjek Vegetarian dan Non-Vegetarian

\begin{tabular}{llll}
\hline \multicolumn{1}{c}{ Variabel } & \multicolumn{1}{c}{$\begin{array}{c}\text { Vegetarian } \\
\mathbf{n = 3 2}\end{array}$} & $\begin{array}{c}\text { Non-Vegetarian } \\
\mathbf{n = 3 2}\end{array}$ & P \\
\hline Indeks Massa Tubuh & $20.44 \pm 2.69$ & $23.57 \pm 5.44$ & $0.019^{\mathrm{b}}$ \\
Asupan Energi & $1.49 \pm 3.87$ & $1.47 \pm 2.87$ & $0.209^{\mathrm{a}}$ \\
Asupan Karbohidrat & $219.75 \pm 62.71$ & $174.24 \pm 45.71$ & $0.002^{\mathrm{b}}$ \\
Asupan Protein & $51.52 \pm 15.59$ & $56.83 \pm 18.08$ & $0.311^{\mathrm{a}}$ \\
Asupan Lemak Total & $53.69 \pm 21.30$ & $62.42 \pm 16.37$ & $0.610^{\mathrm{a}}$ \\
$\quad$ Lemak Jenuh & $23.70 \pm 10.28$ & $35.91 \pm 9.80$ & $0.001^{\mathrm{b}}$ \\
$\quad$ Lemak Tidak Jenuh & $11.3 \pm 4.29$ & $6.98 \pm 2.61$ & $0.001^{\mathrm{b}}$ \\
Asupan Serat & $18.50 \pm 8.73$ & $6.01 \pm 2.08$ & $0.001^{\mathrm{b}}$ \\
Jumlah Leukosit & $7797.81 \pm 2.50$ & $8689.69 \pm 2.35$ & $0.634^{\mathrm{a}}$ \\
\hline \multicolumn{5}{c}{${ }^{\mathrm{a}}$ Uji T Independen } \\
\end{tabular}

\section{PEMBAHASAN}

Penelitian ini dilakukan pada subjek vegetarian yang termasuk dalam kelompok lacto-ovo vegetarian dan vegan serta pada subjek nonvegetarian yang berjenis kelamin perempuan serta berusia 19-29 tahun dimana termasuk dalam rentang usia dewasa yaitu usia 19-40 tahun. Pada usia dewasa, sistem imun tubuh sudah dianggap matang dibandingkan usia balita dan anak-anak namun akan mengalami kemunduran saat menginjak usia lanjut. Selain itu, sistem imun juga turut dipengaruhi oleh hormon, dimana hormon androgen pada laki-laki bersifat imunosupresif atau menekan respon imun dan hormon estrogen pada perempuan dapat menyebabkan fluktuasi jumlah sel T selama siklus haid normal. ${ }^{6}$

Penelitian yang dilakukan menunjukkan hasil bahwa terdapat perbedaan yang signifikan pada indeks massa tubuh $(\mathrm{p}=0.019)$ antara vegetarian dan non-vegetarian. Rerata indeks massa tubuh pada subjek vegan dan lakto-ovo vegetarian lebih rendah dan dalam kategori normal apabila dibandingkan dengan non-vegetarian. Jumlah subjek yang memiliki status gizi kurang pada kelompok vegan sama dengan kelompok non-vegetarian, namun yang memiliki status gizi normal dan status gizi lebih terbanyak pada subjek non-vegetarian. Hal tersebut dapat disebabkan karena adanya perbedaan pola makan antara vegetarian dan non-vegetarian, dimana sebagian besar vegetarian lebih banyak mengonsumsi sayuran dan makanan nabati serta menghindari makanan- makanan yang berasal dari produk hewani dibandingkan dengan non-vegetarian. Sayuran dan makanan nabati memiliki asupan serat yang tinggi, dimana serat dapat menimbulkan rasa kenyang disertai dengan adanya peningkatan waktu pengunyahan yang berpengaruh dalam penurunan tingkat konsumsi energi. Makanan tinggi serat juga memiliki kepadatan energi yang jauh lebih rendah dibandingkan dengan makanan tinggi lemak yang terdapat pada produk hewani, dimana diet rendah padat energi dapat menurunkan konsumsi makanan dibandingkan dengan diet tinggi padat energi. ${ }^{9}$ Hasil penelitian ini sesuai dengan penelitian Akhter et al. pada tahun 2016. ${ }^{10}$

Penelitian ini juga menunjukkan hasil bahwa terdapat perbedaan yang signifikan pada asupan karbohidrat $(\mathrm{p}=0.002)$ dan serat $(\mathrm{p}=0.001)$ antara vegetarian dan non-vegetarian. Rerata asupan karbohidrat dan serat lebih tinggi pada vegan, walaupun asupan-asupan tersebut masih tergolong kurang pada ketiga kelompok subjek. Hal ini dapat disebabkan karena vegan lebih banyak mengonsumsi asupan buah, sayuran, dan kacang-kacangan yang menjadi sumber karbohidrat dan serat apabila dibandingkan dengan kelompok subjek lainnya. Hal ini sesuai dengan penelitian Clarys et al. pada tahun 2014. ${ }^{11}$ Terdapat perbedaan yang signifikan juga pada asupan lemak jenuh $(\mathrm{p}=0.001)$ dan lemak tak jenuh $(\mathrm{p}=0.001)$ antara vegetarian dan non-vegetarian. Rerata asupan lemak jenuh lebih tinggi pada kelompok non-vegetarian, sementara rerata asupan 
lemak tak jenuh lebih tinggi pada kelompok vegan. Hal ini dapat disebabkan karena kelompok nonvegetarian masih banyak mengonsumsi asupan makanan-makanan yang berasal dari produk hewani seperti daging sapi dan daging ayam yang tinggi akan lemak jenuh apabila dibandingkan dengan kelompok non-vegetarian yang lebih banyak mengonsumsi makanan-makanan nabati seperti tahu, tempe, dan kacang-kacangan yang tinggi akan kandungan lemak tak jenuh. Hal ini juga sesuai dengan penelitian Clarys et al. pada tahun $2014 .{ }^{11}$

Penelitian ini juga menunjukkan bahwa tidak adanya perbedaan yang signifikan pada asupan energi, protein, lemak total, dan jumlah leukosit antara vegetarian dan non-vegetarian. Secara deskriptif, asupan protein, lemak total, dan jumlah leukosit lebih tinggi pada non-vegetarian, sementara asupan energi hampir sama antara ketiga kelompok subjek. Hal tersebut sejalan dengan penelitian Rizzo et al. pada tahun 2013 dan Clarys et al. pada tahun 2014. 1, 11 Baik vegetarian maupun non-vegetarian memiliki rerata asupan energi yang sama yaitu tergolong kurang, serta apabila dilihat dari kontribusi karbohidrat, protein, serta lemak terhadap total energi tidak terdapat perbedaan yang signifikan. Proporsi energi dari asupan karbohidrat yang lebih besar pada vegetarian mampu mengimbangi proporsi energi dari lemak yang lebih besar pada non-vegetarian. Hal tersebut dapat menjadi salah satu penyebab tidak adanya perbedaan yang signifikan pada asupan energi antara vegetarian dan non-vegetarian. Sementara itu, rerata asupan protein serta lemak total yang tergolong cukup walaupun lebih rendah pada vegetarian dapat disebabkan karena vegetarian lebih banyak mengonsumsi protein dan lemak yang berasal dari sumber nabati yang memberikan kalori lebih rendah dibandingkan sumber hewani.

Rerata jumlah leukosit pada kelompok vegetarian lebih rendah bila dibandingkan dengan non-vegetarian, namun masih berada dalam kategori normal. Hal tersebut sejalan dengan penelitian Haddad et al. tahun 1999 dan Neubauerova et al. tahun 2007. ${ }^{12,13}$ Sebanyak 7 subjek dari 32 subjek vegetarian $(21.9 \%)$ dan 5 subjek dari 32 subjek nonvegetarian (15.6\%) memiliki jumlah leukosit yang tergolong tidak normal. Hal tersebut dapat disebabkan oleh beberapa faktor antara lain status gizi dan asupan zat gizi makro. Status gizi lebih yang banyak terdapat pada non-vegetarian, dimana merupakan kondisi inflamasi kronis tingkat rendah, dapat menyebabkan pelepasan tumor necrosis factor$\alpha$ (TNF- $\alpha$ ) dan interleukin 6 (IL-6) dalam konsentrasi tinggi dimana sitokin-sitokin pro-inflamasi tersebut berperan sebagai faktor pertumbuhan yang menyebabkan peningkatan produksi leukosit di sumsum tulang. Selain itu, akumulasi lemak viseral dapat menyebabkan kesalahan pengaturan dalam fungsi adiposit yang meliputi kelebihan sekresi TNF- $\alpha$. Obesitas viseral juga menyebabkan rendahnya sekresi dari adiponektin, produk jaringan adiposa yang bersifat anti-inflamasi, dimana TNF- $\alpha$ juga menjadi penghambat terkuat dari aktivitas adiponektin. Oleh karena itu, dapat disimpulkan bahwa kelebihan sekresi TNF- $\alpha$ pada subjek obesitas dapat menurunkan efek anti-inflamasi adiponektin yang mengarah pada inflamasi dan peningkatan leukosit. ${ }^{14}$

Asupan karbohidrat dan serat yang lebih tinggi pada vegetarian, khususnya asupan serat, dapat mempengaruhi status imun yakni menurunkan jumlah leukosit. Asupan serat dari sayur dan buah memiliki kemampuan untuk mengangkut komponenkomponen antioksidan seperti polifenol dan karotenoid melalui usus kecil dan usus besar. ${ }^{15}$ Sebuah penelitian menunjukkan bahwa asupan serat sebanyak 15 gr yang tinggi akan kandungan antioksidan fenolik dapat meningkatkan total antioxidant capacity (TAC) plasma sehingga dapat disimpulkan bahwa antioksidan fenolik yang berhubungan dengan asupan serat dapat meningkatkan ketersediaannya pada manusia. ${ }^{16}$ Antioksidan diketahui dapat menurunkan stress oksidatif dimana antioksidan ini memiliki kontribusi dalam menurunkan sitokin-sitokin inflamasi sehingga menyebabkan penurunan pada jumlah leukosit. ${ }^{17}$

Asupan lemak yang berlebihan, terutama asupan lemak jenuh yang terjadi pada kelompok nonvegetarian, dapat meningkatkan simpanan lemak di dalam tubuh (trigliserida) sehingga mengakibatkan keseimbangan lemak positif dan peningkatan akumulasi jaringan adiposa. Trigliserida diketahui berhubungan dengan peningkatan jumlah sel darah putih di peredaran darah karena trigliserida memberikan suplai energi bagi pembuatan sel darah putih. ${ }^{18}$ Asupan lemak yang berlebihan juga menjadi salah satu faktor penyebab obesitas, dimana pada subjek obesitas ditemukan peningkatan sitokinsitokin pro-inflamasi seperti IL-6 dan IL-8 yang merupakan penginduksi kuat dalam produksi leukosit, dimana produksi sitokin-sitokin tersebut juga dipacu oleh mediator pro-inflamasi yang dikeluarkan oleh jaringan adiposa yaitu angiotensin II. ${ }^{19}$ Sementara itu, tingginya asupan lemak tidak jenuh pada vegetarian, khususnya asupan asam lemak omega-6, dapat menyebabkan penurunan produksi TNF- $\alpha$, dimana TNF- $\alpha$ diketahui merupakan salah satu pemicu peningkatan produksi leukosit. ${ }^{20}$

Asupan protein, khususnya asam amino, dibutuhkan oleh sistem imun, termasuk leukosit dalam mempertahankan fungsi normalnya. Selain itu, telah diketahui juga bahwa protein berfungsi dalam pembentukan antibodi, sehingga jumlah protein yang diasup akan mempengaruhi jumlah antibodi yang 
terbentuk. Sementara pada vegetarian, tingginya asupan protein nabati yang memiliki kandungan asam amino esensial seperti leusin, metionin, lisin, dan triptofan yang cenderung lebih rendah dibandingkan protein hewani dapat mempengaruhi sistem imun. ${ }^{18}$, 19, 21 Namun, apabila dua jenis atau lebih protein nabati dicampurkan dapat menghasilkan protein yang bermutu tinggi sehingga kandungan asam amino esensial yang ada dapat saling melengkapi. Asam amino metionin berperan dalam metabolisme leukosit karena metionin merupakan substrat yang mensintesis kolin, dimana fosfatidil kolin dan asetilkolin dibutuhkan dalam metabolisme leukosit. Asam amino triptofan, dimana produk katabolismenya yang meliputi serotonin, Nasetilserotonin, dan melatonin dapat menghambat produksi superoksida, mengumpulkan radikal bebas, dan menurunkan produksi TNF- $\alpha$. Asam amino lisin, apabila terjadi defisiensi maka akan menyebabkan pembatasan sintesis protein (termasuk sitokin), peningkatan proliferasi limfosit, dan penurunan respon antibodi dan sel-sel lain yang berperan dalam imunitas. Asam amino leusin, yang termasuk dalam BCAA (branched-chain amino acids), merupakan aktivator bagi jalur persinyalan mTOR yang meregulasi sintesis dan degradasi protein dalam sel, sehingga apabila konsentrasi BCAA ekstraseluler berada dibawah kadar plasma yang seharusnya, terutama pada subjek yang menderita malnutrisi, akan mengakibatkan proliferasi limfosit. ${ }^{21,22}$

\section{SIMPULAN}

Terdapat perbedaan yang signifikan pada status gizi, asupan karbohidrat, asupan serat, asupan lemak jenuh, dan lemak tidak jenuh antara vegetarian dan non-vegetarian. Asupan karbohidrat, serat, dan lemak tidak jenuh lebih tinggi pada vegetarian, sementara asupan lemak jenuh dan status gizi lebih tinggi pada non-vegetarian. Secara deskriptif, asupan protein, lemak, dan jumlah leukosit lebih tinggi pada non-vegetarian, sementara asupan energi hampir sama pada kedua kelompok.

\section{SARAN}

Berdasarkan penelitian yang telah dilakukan, dapat dilihat bahwa status imun yang diukur melalui jumlah leukosit, yang tergolong tidak normal cenderung disebabkan karena adanya peningkatan kondisi inflamasi sehingga disarankan bagi para nonvegetarian agar dapat mengikuti pola makan dan pola hidup seorang vegetarian. Sementara bagi para kaum vegetarian, disarankan untuk lebih memperhatikan keseimbangan asupan zat-zat gizi yang dikonsumsi guna mencegah defisiensi zat-zat gizi yang dapat menyebabkan status imun dalam kondisi dan jumlah yang tidak optimal. Penelitian lebih lanjut tentang status imun pada vegetarian dan non-vegetarian disarankan dapat melakukan uji laboratorium terkait biomarker-biomarker lainnya dalam menentukan status imun maupun sistem imun, antara lain limfosit $\mathrm{T}$ dan $\mathrm{B}$, sel natural killer (NK), sitokin, komplemen, dan sebagainya.

\section{UCAPAN TERIMAKASIH}

Terimakasih kepada seluruh subjek dan pihak yang telah berpartisipasi dalam penelitian ini.

\section{DAFTAR PUSTAKA}

1. Akther F, Akter MK, Sen BK, Rahman M, Talukder MU. (2016, Juli). Assessment of nutritional status \& health condition among vegetarian and non-vegetarian adult at Tangail Sadar Upazila in Tangail District. International Journal of Nutrition and Food Sciences, 5(4), 241-245.

2. Baecke JAH, Burema J, Frijters JER. (1982, Desember). A short questionnaire for the measurement of habitual physical activity in epidemiological studies. The American Journal of Clinical Nutrition, 36(5).

3. Baratawidjaja KG, Rengganis I. (2012). Imunologi Dasar (10th ed.). Jakarta: Badan Penerbit Fakultas Kedokteran Universitas Indonesia.

4. Bonaccio M, Di Castelnuovo A, De Curtis A, Costanzo S, Persichillo M, Donati MB et al. (2014, Mei). Adherence to the Mediterranean diet is associated with lower platelet and leukocyte counts: results from the Moli-sani study. Blood, 123(19), 3037-44.

5. Calder PC. (2007). Immunological parameters : what do they mean? The Journal of Nutrition, $137,773 \mathrm{~S}-780 \mathrm{~S}$.

6. Carpenter KC, Strohacker K, Breslin WL, Lowder TW, McFarlin BK. (2011, April). Voluntary wheel running during weight loss leads to differential changes in monocytes, compared to forced treadmill running. International Journal of Exercise Science, 2(3).

7. Clarys P, Deliens T, Huybrechts I, Deriemaeker P, Vanaelst B, Keyzer WD et al. (2014, Maret). Comparison of nutritional quality of the vegan, vegetarian, semi-vegetarian, pesco-vegetarian and omnivorous diet. Nutrients, 6(3), 13181332.

8. de Pablo MA, Alvarez de Cienfuegos G. (2000, Februari). Modulatory effects of dietary lipids on immune system functions. Immunology and Cell Biology, 78(1), 31-39.

9. Ford JT, Wong CW, Colditz IG. (2001). Effects of dietary protein types on immune responses 
and levels of infection with Eimeria vermiformis in mice. Immunology and Cell Biology, 79(1), 23-28.

10. Haddad EH, Berk LS, Kettering JD, Hubbard RW, Peters WR. (1999, September). Dietary intake and biochemical, hematologic, and immune status of vegans compared with nonvegetarians. The American Journal of Clinical Nutrition, 70(3 suppl), 586S-593S.

11. Kosteli A, Sugaru E, Haemmerle G, Martin JF, Lei J, Zechner R et al. (2010, Oktober). Weight loss and lipolysis promote a dynamic immune response in murine adipose tissue. The Journal of Clinical Investigation, 120(10), 3466-3479.

12. Li P, Yin YL, Li D, Kim SW, Wu G. (2007). Amino acids and immune function. British Journal of Nutrition, 98(2), 237-252.

13. Neubauerova E, Tulinska J, Kuricova M, Liskova A, Volkovova K, Kudlackova $\mathrm{M}$ et al. (2007, September). The effect of vegetarian diet on immune response. Epidemiology, 18(5), S196.

14. Pérez-Jiménez J, Serrano J, Tabernero M, Arranz S, Díaz-Rubio ME, García-Diz L et al. (2009, Juni). Bioavailability of phenolic antioxidants associated with dietary fiber: plasma antioxidant capacity after acute and longterm intake in humans. Plant Foods for Human Nutrition, 64(2), 102-107.

15. Rizzo NS, Jaceldo-Siegl K, Sabate J, Fraser GE. (2013, Desember). Nutrient profiles of vegetarian and non vegetarian dietary patterns. Journal of The American Academy of Nutrition and Dietetics, 113(12).

16. Rolfes SR, Pinna K, Whitney E. (2009). Understanding normal and clinical nutrition (8th ed.). Canada: Wadsworth, Cengage Learning.

17. Ruan T, Li L, Peng X, Wu B. (2017, Mei). Effects of methionine on the immune function in animals. Health, 9(5).

18. Saura-Calixto F. (2011, Januari). Dietary fiber as a carrier of dietary antioxidants: an essential physiological function. Journal of Agricultural and Food Chemistry, 59(1), 43-49.

19. Shastri N, Paunikar VM, Baig MNH. (2012). Association of obesity with total leukocyte count in patients of metabolic syndrome. International Journal of Biological and Medical Research, 3(1), 1399-1401.

20. Slavin JL. (2005, Maret). Dietary fiber and body weight. Nutrition, 21(3), 411-8.

21. Sufiati B, Kusuma HS, Ulvie YNS, Mulyati T. (2016). Perhitungan Kebutuhan Gizi Individu. Semarang: NextBook.
22. Zhang Z, Shi L, Pang W, Liu W, Li J, Wang H et al. (2016). Dietary fiber regulates intestinal microflora, and inhibits allergic airway inflammation in a mouse model. PLOS ONE, $11(2)$. 